would be a considerable thickness of Oolitic strata over the Palzozoics; but a boring there proved the carboniferous limestone at 59 feet from the surface.

It is generally conceded that if the sole object of the exploration were to search for coal measures under the sonth-east of England, it might have been advisatle to bore more to the north or north-east. There is no doubt that the Oolitic strata thin in that direction, so that a boring between Maidstone and Folkestone would probably not meet with any, or vith only a small thickness. I3ut, on the other hand, the Lower Cretaceous strata might there be thick. Borings for pyater at Maidstone have been carricd to 600 feet below sea-level, and only just pierced the Weald clay, getting water from the top beds of the Hastings sands. A boring at Aslyford, carried to about the same depth, seens to have got inio the Hastings sand series; but how much more Wealden strata may be below either of these bore-holes we cannot tell. Prof. Prestwich supposes that the Palæozoics may lie at a more moderate depth below the sea-level at Folkestone; and he proposes that the Channel Tunnel should be carried through these old rocks. We must all hope, and I for one believe, that the Tunnel can be successfully carried through the chalk; but if this should fail, it is proballe that borings will be made to test the feasibility of Prof. Trest wich's scheme. Meanwhile, the Sub-Wealden Exploration can apply its funds in investigating other districis.

It should be remembered that the boring has been mainly supported by landowners and olhers cennected with Sussex. Mr. Willett, the indefatigable secretary, has worked at the task that Susse $x$ may have the honour of leading in an exploration which in future years, whatever may be the success of the present boring, will certainly be extended to other districts in the southeast of England. It is ccrtain that no other spot in Sussex is so well suikd for the work; and, all things considered, the best plan is to begin again on the samie site.

The Committee has always kept the coal question in the background, preferring to urge forward the work on its scientific merits. Stiil, it is true that the chief cause of the wide interest taken in the boring is the hope that coal will be found, or at least that valuable information bearing on the point will be ubtained. It may then be well ayain to call attention to the fact that Prof. Gosselet, whose researches on the Coal Mieasures of Northern France are so well known, believes that the boring is in the right position, and that it is very probable that a lice of productive coal measures underlies the Weald. He has sirown that the coal beds of Hardinghen, in the Boulonnais, are really true coal measures faultcd down, and are not an abnormal development of the limestone series; a conclusion with which other geckogists now agree.

I liave entered into these long explanations from a fear les Mr. llake's well-meaning criticisms may convey the impression that money is now to be spent at Netherfield which could be better spent elsewhere. I think this is not the case, and I hope that those who have the means and the will may see the import ance of aiding the work with their contrilutions. Mr. M. Willett (Arnold House, Brighton) has made himself persona?ly responsible for the amount (600\%) needcd to carry the new boring down to 1,000 feet, trusting that subscriptions will steadily come in for the future as they have done in the past.

Geological Survey Office, Jermyn Street, London, $\mathrm{Feb} .7$

\section{W. TOHEY}

\section{Gaussian Constanis}

PROF. HUMP'iREY LLOY1) says, in his book "On Magnetism," published about two months ago, and reviewed (vol. xi. p. 221) in NATURE by Prof. Balfour Stewart, on page 115 , in a paragraph on "Gauss's Theory" :- "In addition to this, mainly through the exertions of General Sahine, magnetical observations have been vastly multiplied at other points of the earth's surface; and the time has consequently arrived when a re-calculation of the Gaussian constants, as they are called, may with advantage be undertaken. This laborious work is now in progress. General Sabine has completed the co-ordination of the observations, and Prof. Adams has generously offered to devote his valuable time to the re-calculation based upon them. The scientific world may therefore, before long, expect to see a sexies of charts exhibiting the actual condition of the earth's magnet. ism greatly more exact than any which have been yet produced."

It may therefore interest Prof. Lloyd and others to hear that about nine months ago was edited and published at Berlin, at the request of the Imperial Admiralty, "Die Grundlagen der Gaussischen Theorie und die Erscheinungen des Erdmagnetismus im Jahre 1829, mit Beruicksichtigung der Sæcularvariationen aus allen vorliegenden Beobachtungen berechnet und dargestellt, von A. Erman und H. Petersen;" a re-calculation of the "Ganssian Constants," based on a co-ordination of the most reliable observations, containing a series of charts which exhibit the actual condition of the earth's magnetism.

O. REICHENBACH

\section{Columnar Formation in Mud Panks}

IN reference to the report in NATURE, vol, xi. p. 258, on Mr. Mallet's commumication to the Royal Society, respecting the hexagonal crystallisation of basalt, I beg to offer to your readers a similar explanation of the columnar formation in some mud banks on the shores of some of the rivers in South Africa.

The modern clianrels are gradually becoming lower than formerly, owing to the rising of the land, and so the streams in estuaries and reaches have cut out deeper courses in the previously formed muddy bottoms, and these are now cxposed on the sides of the rivers, but at the bottom of the valleys, to the action of the sun and the hot winds. These strata of mud are very thick, and they begin to dry on the surface, and split across into hexagonal-like rises all over the flit, and this splitting on the suriace gradually deepens into the stratum, and a mass or confreries of columns is thus formed on the side lying nearest the river. The diameter of these columns may vary from 4 to 9 inches, but their length is very uncertain, and might be from I to 3 feet. These again become detached by gravity, rains and winds, and tumble into the stream, and are borne away by the currents to the sea, to become imbedded and fossilised in some sand-bank, and probably the study of some fature palieontologist.

In the case of basalt the arency of crustailisation is stated to be by Mr. Maliet the absiraction of heat and contraction of fluidity into solidity; but in this case it may be attributed to loss of moisture by heat and dryness producing contraction of fluidity into solidity. A similar result would therefore appear to be produced by apparently two opposite causes, cooling in the one case and heating in the other, but both have tended to produce a closer aggregation of the molecules, and brought them $\mathrm{u}$ ithin the range of their peculiar physical afinities. Edinburgh

J. W. BLACK

\section{Flowers and Bees}

Winis reference to a letter which appeared in NATURE, vol. xi. p. 248, I may mention that on the 3oth of August last nearly all the Snapdragon flowers I could find (including many unopened buds) had bien bitten through by bees. I had been looling out for flowers in this state a stort time before (I think not murc than a week), when I could find only two, and those looked as if they might have been accionentally injured. The quickness and tioroughness with which the work isad been done was very striking.

C. A, M.

\section{Iron Pyrites}

IN NAIURE, vol. xi. p. 249, Mr. Carr mentions the fact that some iron pyrites in the Maidstone Museum "have crumbled into a coarse, finely divided mass;" and he inquires whether "such a thing has ever been observed befure." It is a very common and well-known fact, and any work on chemistry will explain it. Per. liaps we can best answer the question by quoting Dr. Miller on the subject (Chemistry, p. 588):- "Some varieties of iron pyrites, especially those found in the Tertiary strata, are speedily decomposed by exposure to air; oxygen is absorbed, and ferrous sulphate formed. This decomposition occurs with greater facility if the disulphide be mixed. with other substances, as is the case in the aluminous schists; in which, by the further action of air, a basic ferric sulphate is formed, whilst the liberated sulphuric acid reacts upon the alumina, magnesia, or lime of the soil, and forms sulphates; those of aluminium and magnesia may be extracted by lixiviation. The ordinary crystallised pyrites from the older strata is not thus decomposed, but a variety of a whiter colour is disintegrated rapidly by exposure to the weather; this form of pyrites is known as Marcasite, or white iron pyrites." 